\title{
KIAI LANGGAR SEBAGAI EPISENTRUM PENDIDIKAN ISLAM MASYARAKAT DESA MENINJO RANUYOSO LUMAJANG
}

\author{
Robiatul Adawiyah \\ Institut Agama Islam Syarifuddin Lumajang, Indonesia \\ E-mail: rubiadawiyah150@gmail.com \\ Ahmad Ihwanul Muttaqin \\ Institut Agama Islam Syarifuddin Lumajang, Indonesia \\ E-mail: ihwanmuttaqin@gmail.com
}

\begin{abstract}
Abstrak: Artikel ini hendak mengungkapkan peran Kiai Langgar yang dalam berbagai riset tidak banyak diulas dalam berbagai penelitian sebagaimana Kiai Pesantren. Langgar sebagaimana disebutkan dalam berbagai literatur menjadi penyokong dan penguat pendidikan Islam di level akar rumput. Bahkan, langgar menjadi entrypoint masuknya pendidikan Islam untuk masyarakat yang ingin belajar Islam, jauh sebelum pesantren. Penelitian ini dilakukan di Desa Meninjo Kecamatan Ranuyoso Kabupaten Lumajang dengan pendekatan kualitatif untuk memperdalam hasil temuan. Dari hasil penelitian, didapati kesimpulan sebagai Kiai Langgar memiliki peran yang cukup signifikan antara lain sebagai sarana meningkatkan keimanan masyarakat, penjaga moral dan nilai keIslaman di masyarakat hingga menjadi gerbang masuknya ilmu pengetahuan Islam yang akhirnya menjadi norma yang disepakati bersama di tengah-tengah masyarakat. Respon masyarakat terhadap peran Kiai Langgar juga beragam. Tetapi keseluruhan masyarakat menjadikan Kiai Langgar sebagai sosok yang sentral dalam berbagai dinamika kehidupan. Peran inilah yang menjadikan Kiai Langgar sebagai episentrum pendidikan Islam.
\end{abstract}

Kata kunci: Kiai langgar, pendidikan Islam

\section{Pendahuluan}

Langgar (musholla) adalah pendidikan Islam tertua di Indonesia yang telah tumbuh dan berkembang di komunitas Islam. Hal ini didirikan lebih awal dari pesantren (Pesantren), sekolah dan madrasah. Langgar telah mengambil peran penting dalam mempersiapkan generasi Alquran. ${ }^{1}$

Langgar di pimpin oleh seorang kiai sebagai aktor sosial yang lekat dengan aspek agama, pada perkembangannya dapat memunculkan diri sebagai kiai itu sendiri atau seorang agamawan sekaligus tokoh masyarakat. Konsep pertama biasanya digunakan dalam kajian yang lebih netral dalam melihat ketokohan dan aktivitas kiai terhadap umatnya, yaitu cara seorang kiai melakukan dakwah, cara dan metode, dan beberapa kajian mengenai kekuatan pengaruh kiai terhadap lingkungannya. ${ }^{2}$

Di masyarakat, kiai menduduki peran top leader dengan memiliki wewenang yang besar dalam aspek kehidupan. Hal ini, karena secara tradisi masyarakat mengaitkan dirinya dengan etos spiritual atau mistik, di mana setiap aspek kehidupan orang Jawa senantiasa memiliki makna

\footnotetext{
${ }^{1}$ Moh. Wardi "Pilihan Belajar Al-Qur'an di Madura; Konversi Dari Langgar Ke Taman Pendidikan Al-Qur'an", Jurnal Kabilah, vol. 1, no. 1 (Juni 2019), 93.

2 Sayfa Auliya Achidsti, "Eksistensi Kiai dalam Masyarakat" Jurnal Kebudayaan Islam, vol. 12, no. 2 (Juli-Desember 2014), 149.
} 
batin/rasa yang bersifat spiritual. Pada umumnya mereka merupakan pembuat keputusan yang efektif dalam sistem kehidupan sosial orang Jawa, tidak hanya dalam kehidupan beragama tetapi dalam soal-soal politik. ${ }^{3}$

Langgar sebagai institusi terkecil dan non formal pendidikan Islam yang paling awal keberadaannya dibanding madrasah dan sekolah Islam yang datang kemudian. Langgar dikenal sebagai lembaga pendidikan Islam tingkat pemula dan pesantren sebagai lembaga pendidikan tingkat lanjut. Kedua lembaga ini telah banyak berperan mengIslamkan Nusantara/Indonesia dalam waktu yang cukup lama. ${ }^{4}$

Langgar sebagai pusat pendidikan desa memiliki relasi substansial dan fungsional, yakni menjadi wahana berlangsungnya aktivitas kependidikan Islam yang berfungsi sebagai instrumen penanaman akidah dan doktrin-doktrin keIslaman. ${ }^{5}$ Sebagaimana hal ini yang tercermin di desa Meninjo kecamatan Ranuyoso Kabupaten Lumajang dimana Langgar menjadi sentral dalam memupuk pemahaman masyarakat atas pentingnya pendidikan Islam. ${ }^{6}$

Masyarakat desa Meninjo memandang petuah-petuah Kiai Langgar adalah suatu hal yang wajib untuk dilakukan. Dengan demikian, pendidikan Islam masyarakat Meninjo ditengarai berada di pundak Kiai Langgar yang memiliki peranan yang sangat penting dalam mensosialisasikan pentingnya pendidikan tingkat lanjut ke pesantren hingga kepada perguruan inggi keislaman.

pendidikan Islam merupakan sekaligus pendidikan amal. Dan karena ajaran Islam berisi tentang ajaran sikap dan tingkah laku pribadi masyarakat menuju kesejahteraan hidup perorangan dan bersama, maka orang pertama yang bertugas mendidik masyarakat adalah para Nabi dan Rasul, selanjutnya para ulama' dan cerdik pandai sebagai penerus tugas dan kewajiban mereka.

Pendidikan Islam yang berarti proses bimbingan dari pendidik terhadap perkembangan jasmani, rohani, dan akal peserta didik kearah terbentuknya pribadi muslim telah berkembang di berbagai daerah dari sistemnya yang paling sederhana menuju sistem pendidikan Islam modern.

Pendidikan Islam sebagai proses yang mengarahkan manusia kepada kehidupan yang baik yang mengangkat derajat kemanusian sesuai kemampuan dasar (fitroh), penting sekali diberikan kepada peserta didik, terutama dalam mengantisipasi krisis moral sebagai dampak negatif dari era globalisasi yang melanda bangsa Indonesia. ${ }^{8}$

\footnotetext{
${ }^{3}$ Mawarti Wawardi “Persepsi Masyarakat Terhadap Peran Kiai di Daerah Istimewa Yogyakarta”, Jurnal Medan Agama, Desember 2014, 134.

${ }^{4}$ Syamsudini "Daya Tahan Penddikan Langgar Di Tengah Arus Modernisasi Pendidikan Islam", Jurnal al-'Adâlah, Vol 19, No 2, November 2016, 19.

5 Moh. Slamet Untung "Telaah Historis Pertumbuhan Pusat Pendidikan Islam Di Jawa Sampai Periode Perang Jawa" Jurnal Forum Tarbiyah, Vol. 8, No. 2, Desember, 215-216.

${ }^{6}$ Eko, Wawancara, Meninjo, 10 Maret 2019. "Salah seorang yang berperan sebagai Kiai Langgar di Desa Meninjo"

${ }^{7}$ Hamdani Ihsan dan A. Fuad Ihsan, Filsafat Pendidikan Islam (Bandung: CV Pustaka Setia, 2001), 17.

8 Akh Muzakki dan Kholilah, Ilmu pendidikan Islam (Surabaya: Kopertais VI Press, 2010), 1.

2 | Tarbiyatuna: Jurnal Pendidikan Islam; Volume 13, Nomor 1, Februari 2020 p-ISSN: 2085-6539; e-ISSN: 2242-4579
} 
Pendidikan Islam adalah pendidikan menurut Islam atau pendidikan Islami, yakni pendidikan yang dipahami dan dikembangkan dari ajaran dan nilai-nilai fundamental dan terkandung dalam sumber dasarnya, yaitu Al-Qur'an dan as-Sunnah. Dalam pengertian pertama ini, pendidikan Islam dapat berwujud pemikiran dan teori pendidikan yang mendasarkan diri atau dibangun dan dikembangkan dari sumber-sumber dasar tersebut atau bertolak dari spirit Islam. ${ }^{9}$

Dasar-dasar pendidikan Islam adalah nilai-nilai sosial kemasyarakatan yang tidak bertentangan dengan ajaran-ajaran Al-Qur'an dan Sunnah atas prinsip mendatangkan kemanfaatan dan menjauhkan dari kemudhratan bagi manusia. ${ }^{10}$

Nilai-nilai Islam demikian itulah yang seharusnya ditumbuhkembangkan dalam diri manusia melalui proses transformasi kependidikan. Suatu proses yang bisa mengarahkan seseorang selalu berorientasi kepada kekuasaan Allah dan Iradat Nya dalam menentukan segala keberhasilannya. ${ }^{11}$

Dalam hal ini nilai-nilai Islam memiliki peranan yang sangat penting agar manusia dididik sehingga mampu mengenali dan merealisasikan tujuan dalam hidupnya sebagaimana yang telah digariskan yaitu beribadah kepada Allah SWT. Hal ini tergambar dalam firman Allah SWT Surah Al-Anbiya' ayat 25 :

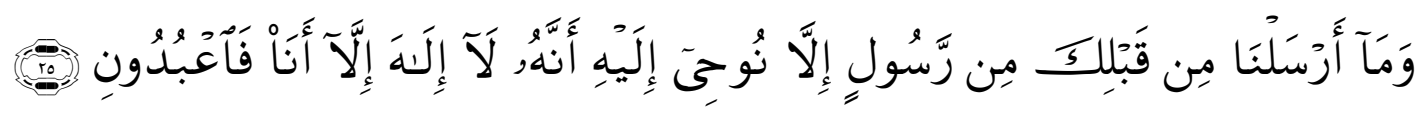

Artinya : "Dan kami tidak mengutus seorang Rasulpun sebelum kamu melainkan Kami wahyukan kepadanya: "Babwasanya tidak ada Tuban (yang hak) melainkan Aku, Maka sembablah olehmu sekalian akan aku". (QS. Al-Anbiya': 25). ${ }^{12}$

Kiai langgar di Desa Meninjo merupakan salah satu tokoh yang sangat berperan terhadap masayarakat. Kiai langgar menanamkan pendidikan Islam terhadap santri-santrinya seperti mengajarkan bagaimana cara membaca Al-Qur'an yang benar, pengajian kitab kuning, tata cara sholat, istighosah dan lain sebagainya. Hal tersebut tidak luput dari kerja sama antara kiai langgar, santri dan masyarakat. Sehingga nantinya masyarakat mempunyai, memahami, dan menerapkan pendidikan Islam dalam kehidupan sehari-hari.

\section{Kiai Langgar}

Kiai adalah istilah budaya (bermula dari Jawa). Orang Jawa biasa menyebut kiai, siapa atau apa saja yang mereka puja dan mereka hormati. Kiai Sabuk Inten, Kiai Nagasasra, Kiai Plered, misalnya, sebutan untuk senjata; Kiai Slamet sebutan untuk kerbau di Keraton Surakarta. Bagi orang Jawa orang yang disebut kiai semula adalah mereka yang dipuja dan dihormati masyarakat

\footnotetext{
${ }^{9}$ Mujtahid, Reformasi Pendidikan Islam (Malang: UIN Malang Press, 2011), 18.

${ }^{10}$ Azyumardi Azra, Pendidikan Islam: Tradisi dan Modernisasi Menuju Milenium Baru (Jakarta: Penerbit Kalimah, 2001), 9.

${ }^{11}$ Arifin, Ilmu Pendidikan Islam Timjauan Teoritis dan Praktis Berdasarkan Pendekatan Interdisipliner (Jakarta: Bumi Aksara, 2003), 2.

${ }^{12}$ QS. Anbiya', : 25
} 
karena ilmunya, juga jasa dan rasa kasih sayang mereka kepada masyarakat. Dulu, kiai yang umumnya tinggal di desa benar-benar kawan masyarakat menjadi tumpuan, tempat bertanya dan meminta, juga pertolongan. Sebaliknya, kiai yang dipuja dan dihormati masyarakat itu memang mencintai masyarakat dan seperti mewakafkan dirinya untuk mereka. Kiai yang termasuk golongan mereka yang "yanzhuruuna ilal ummah bi'ainir rahmah", melihat umat dengan mata kasih sayang, memberikan pelajaran kepada yang bodoh, membantu yang lemah, menghibur yang menderita dan seterusnya. Komplek pesantren yang umumnya 100 persen dibangun kiai adalah bukti perjuangan dan pengabdian kiai kepada masyarakat. ${ }^{13}$

Istilah langgar dipakai untuk menunjuk bangunan kecil biasanya berbentuk segi empat seperti bangunan masjid namun lebih kecil, yang berdiri di sekitar rumah-rumah komunitas muslim. Secara umum bangunan tersebut digunakan sebagai tempat ibadah salat (selain salat jum'at). Oleh karena itu, langgar sering disebut pula musolla (tempat shalat). Selain sebagai tempat shalat, beberapa langgar menjadi tempat belajar agama tingkat dasar. ${ }^{14}$

\section{Langgar Sebagai Lembaga Pendidikan Islam}

Dalam lingkup pendidikan Islam di Indonesia, khususnya di Jawa-Madura, langgar dikenal sebagai salah satu lembaga pendidikan Islam tradisional. Lembaga ini telah mengambil peran tidak kecil dalam pewarisan nilai-nilai Islam antar generasi, utamanya untuk tingkat pemula. Bentuk bangunan yang sederhana dan pola pengajaran yang jauh dari kesan formal menyebabkan langgar banyak ditemukan di sekitar rumah-rumah penduduk. Langgar menjadi pilihan kebanyakan orang tua terutama di wilayah pedesaan untuk mendidik anak-anak mereka sebelum menginjak ke jenjang pendidikan agama yang lebih tinggi. ${ }^{15}$

Dalam beberapa hal, langgar sebagai pusat pendidikan Islam tradisional menjadi simbol bagi kesatuan umat setempat yang lazim dipimpin seorang modin (berasal dari kata imam ad-din) atau Kiai Langgar. Sejak awal pertumbuhannya, langgar bukan saja sebagi tempat ibadah terutama shalat, akan tetapi ia merupakan sentra masyarakat Islam lokal. Para modin atau Kiai Langgar merupakan seorang 'patriarch' yang memimpin umat Islam dalam kehidupan sehari-hari. Di samping sebagai guru ngaji, seorang modin atau Kiai Langgar juga seorang imam shalat dan sekaligus sebagai orang yang dipandang 'sepuh' dalam komunitasnya. Pada masa awal pertumbuhannya, sebagian besar langgar didirikan atas prakarsa pribadi pemiliknya. Warga desa yang kaya atau mereka yang pulang dari menunaikan ibadah haji mendirikan langgar di

\footnotetext{
${ }^{13}$ Mawarti Wawardi "Persepsi Masyarakat Terhadap Peran Kiai", 134.

${ }^{14}$ Mohammad Kosim, "Langgar Sebagai Institusi Pendidikan Keagamaan Islam”, Jurnal Tadrîs, Vol 4, No 2. 2009, 237.

15 Syamsudini "Daya Tahan Penddikan Langgar Di Tengah Arus Modernisasi Pendidikan Islam", Jurnal al'Adâlah,Vol 19, No 2, November 2016, 197.

4 | Tarbiyatuna: Jurnal Pendidikan Islam; Volume 13, Nomor 1, Februari 2020 p-ISSN: 2085-6539; e-ISSN: 2242-4579
} 
pekarangan rumah mereka. Di samping memiliki makna religius bagi si pemilik langgar, mendirikan langgar bermakna prestise yang tinggi. Belajar di langgar dikenal ngaji/ngaos atau ngaji alip-alipan karena yang dipelajari ialah huruf-huruf dasar Arab (hijaiyah dari alif sampai wawu). Dan karena ngaji itu diselingi hafalan ayat-ayat atau surat-surat pendek dari Alqur'an, maka belajar di langgar disebut pula ngaji apalan/turutan. Mereka yang telah menamatkan (khatam) pelajaran di langgar dapat melanjutkan pengajian kitab di pesantren. ${ }^{16}$

\section{Sistem Pendidikan Langgar}

Sebagai institusi pendidikan nonformal, penyelenggaraan pendidikan langgar berlangsung jauh dari kesan formal sebagaimana terlihat di sekolah dan madrasah. Kendati demikian, jika dipahami lebih seksama, terdapat sejumlah unsur yang saling terkait dan membentuk sebuah sistem pendidikan langgar.

Unsur-unsur dimaksud meliputi: ${ }^{17}$ tujuan, materi pelajaran, pengasuh, santri, metode, dan evaluasi.

1. Tujuan, menumbuhkembangkan potensi keberagamaan santri melalui pemberian, pemupukan, dan pengembangan pengetahuan, penghayatan, pengamalan, pembiasaan, serta pengalaman peserta didik tentang agama Islam tingkat dasar dalam rangka menyiapkan manusia muslim yang terus berkembang keimanan dan ketakwaannya kepada Allah SWT.

2. Materi Pembelajaran, Meteri pembelajaran langgar meliputi aspek-aspek al-Qur'an, Aqidah, Akhlak, dan Fiqih, yang dalam praktiknya terwujud ke dalam materi pembelajaran al-Qur'an, rukun Islam, rukun iman, zikir atau do'a pendek, dan hubungan dengan sesama.

3. Metode Pembelajaran, Pengajian al-Qur'an menggunakan sistem sorogan. Para santri biasanya duduk mengelilingi kiai, satu persatu mereka maju menghadap kiai untuk membaca pelajaran yang telah dicapainya. Ketika seorang santri maju, yang lainnya tetap membaca dengan suara keras, sehingga suasana agak gaduh dengan suara santri mengaji. Di masa awal, cara belajar alQur'an menggunakan pola tradisional yang diawali dengan belajar membaca huruf arab melalui langkah-langkah berikut;

4. Santri belajar melafalkan satu persatu huruf arab menurut Qaidah Baghdadiyah, yaitu; alif, ba, ta', tsa', jim, ha', kha', dal, dzal, ra', za', sin, syin, shat, dhat, tha', dzo', 'a'in, ghin, fa', qaf, kaf, lam, mim, nun, wau, ha', lam alif, ya.' Santri diajari mengenal lebih dekat masingmasing huruf dengan menyebut tandanya, misalnya; alif tidak bertitik, $b a$ ' satu titik di bawah, $t a$ ' dua titik di atas, tsa' tiga titik di atas, jim satu titik di bawah, ha' tidak bertitik, kha' satu titik di atas, demikian

\footnotetext{
${ }^{16}$ Moh. Slamet Untung "Telaah Historis Pertumbuhan Pusat Pendidikan Islam Di Jawa Sampai Periode Perang Jawa" Jurnal Forum Tarbiyah, Vol. 8, No. 2, Desember, 227.

${ }^{17}$ Mohammad Kosim, "Langgar Sebagai Institusi Pendidikan Keagamaan Islam”, Jurnal Tadrîs, Vol 4, No 2. 2009, 241.
} 
seterusnya sampai santri paham betul dan bisa membedakan satu huruf dengan huruf lainnya. Santri diajarkan mengeja jenis-jenis harkat ketika dipasangkan dengan huruf tertentu. Caranya ejaannya seperti berikut; alif di atas $a$, alif di bawah $i$, alif di depan $u ; b a^{\prime}$ di atas $b a$, $b a^{\prime}$ di bawah $b i$, ba' di depan $b u$; ta' di atas $t a, t a$ ' di bawah $t i, t a$ ' di depan $t u$; $t s a$ ' di atas $t s a$, Santri dikenalkan dengan tanda harkat ganda atau tanwin dengan cara mengeja, misalnya; alif dua di atas an, alif dua di bawah in, alif dua di depan un; ba' dua di atas ban, ba' dua di bawah bin, $b a^{\prime}$ dua di depan bun; $t a$ ' dua di atas tan, $t a$ ' dua di bawah tin, ta' dua di depan tun; demikian seterusnya. Santri dilatih belajar membaca al-Qur'an dengan menggunakan al-Qur'an Juz 'Amma. Pelajaran dimulai dari belajar membaca surat al-Fatibah lalu Juz 'Amma (dari surat an-Nas, alFalaq, al-Ikhlas, dan seterusnya ke depan).

\section{Peran Kiai Langgar dalam Masyarakat}

Secara umum peran Kiai Langgar dalam kehidupan masyarakat masyarakat di diskripsikan sebagai berikut: ${ }^{18}$

1. Pendidik Agama

Kiai merupakan padanan dari kata ulama'. Karena itu, tugas dasar kiai adalah mengajarkan ilmu-ilmu agama kepada msyarakat. Namun dalam konteks sejarah sosial Indonesia, selain berperan sebagai pendidik agama, kiai juga mengandung arti sebagai orang yang dihormati pendidikan agama. Dengan demikian juga tidak semata-mata mengajarkan agama kepada umat, tetapi menginternalisasikan ke dalam kehidupan kiai itu sendiri sehingga apa yang dilakukan dan diucapakan untuk orang lain juga dilakukan dirinya sendiri.

2. Penjaga Moral

Selain pendidik agama otomatis kiai-Kiai Langgar juga penjaga penjaga moral masyarakat pedesaan. Keberadaanya yang menyatu dikehidupan sehari-hari masyarakat pedesaan mengahruskan berperilaku sebagai penjaga moral dan berperilaku sesuai nilai-nilai moral. Keterlibatan Kiai Langgar dalam penegakan moral masyarakat bisa dikatakan menjadi bagian paling kritis dalam kehiduannya karena fungsi ini serig kali menyebabkan bersinggungan dengan orang atau kelompok lain. Karena kebijaksanaan dan kearifannya dalam melaksanakan tugas melayani masyarakat dengan hatib, seorang Kiai Langgar bisa lebih diterima dan disegani oleh masyarakat.

${ }^{18}$ M. Hanif Dhakri, Kiai langgar dan Demokrasi Lokal (Yogyakarta: KLIK, 2007), 34

6 | Tarbiyatuna: Jurnal Pendidikan Islam; Volume 13, Nomor 1, Februari 2020 
3. Ahli Hikmah

Beberapa Kiai Langgar juga menjadi tokoh lokal yang menonjol karena dianggap mempunyai kelebihan dalam hal ilmu hikmah yang berfungsi membantu masyarakat dalam menghadapi atau menyelesaikan persoalan yang dihadapi.

4. Pemimpin Komunitas

Sebagai pendidik agama Islam, penjaga moral masyarakat dan tempat masyarakat meminta bantuan tentang berbagai persoalan kehidupannya, Kiai Langgar menjadi semacam rujukan bagi masyarakat dalam berbagai kehidupan. Disadari atau tidak dengan fungsi seperti itu, Kiai Langgar bisa dikatakan sebagai pemimpin komunitas yang terpilih secara alamiah. Seorang Kiai Langgar menjadi pemimpin tanpa rekayasa politik dan masyarakat menerima kepemimpinannya dengan sukarela.

5. Pembimbing untuk perubahan

Kiai Langgar juga berperan sebagai pemandu utama masyarakat menghadapi dan melaksanakan perubahan. Salah satu kelebihan Kiai Langgar adalah sifat pengajarannya yang menyeluruh melalu semua aspek kehidupan praktis masyarakat dan pengayaan ruang batinnya dengan nilai-nilai karakter yang diajurkannya. Kecenderungan demikian menjadikan Kiai Langgar memiliki peran penting dalam setiap perubahan masyarakat.

\section{Pengertian Pendidikan Islam}

Istilah pendidikan dalam konteks Islam pada umumnya mengacu kepada al-tarbiyah, al-ta'lim dan al-ta'dib. Dari ketiga istilah tersebut term yang populer digunakan dalam praktek pendidikan Islam adalah al-tarbiyah. Sedangkan al-ta'dib dan al-ta'lim jarang digunakan. ${ }^{19}$ Berikut penulis akan menjelaskan mengenai tiga kosa kata tersebut:

1. Al-Tarbiyah

Kata al-Tarbiyah dalam bahasa Arab, Rabba, yarbu, tarbiyah: memiliki makna "tumbuh" "berkembang", tumbuh (nasya'a) dan menjadi besar atau dewasa (tara'ra'a). Artinya, pendidikan (tarbiyah) merupakan usaha untuk menumbuhkan dan mendewasakan peserta didik, baik secara fisik, psikis, sosial, maupun spiritual. Qurtubi seperti yang dikutip oleh sahrodi mengatakan bahwa "Rabb" merupakan suatu gambaran yang diberikan kepada suatu perbandingan antara Allah sebagai pendidik dan manusia sebagai peserta didik. Allah mengetahui dengan baik kebutuhan-kebutuhan mereka yang dididik, sebab ia adalah pencipta

19 Abdul Halim, Filsafat Pendidikan Islam: Pendekatan Historis, Teoris dan Praktis (Jakarta: Ciputat Pers, 2002), 25. 
mereka. Disamping itu pemeliharaan Allah tidak terbatas pada kelompok tertentu. Ia memperhatikan segala ciptaan-Nya. Karena itulah Ia disebut Rabb al-' Alamin. ${ }^{20}$

Tarbiyah dapat juga diartikan dengan "proses transformasi ilmu pengetahuan dari pendidik (rabbanı) kepada peserta didik agar ia memiliki sikap dan semangat yang tinggi dalam memahami dan menyadari kehidupannya, sehingga terbentuk ketakwaan, budi pekerti, dan kepribadian yang luhur". ${ }^{21}$

Sebagaimana pada ayat Al-Qur'an berikut :

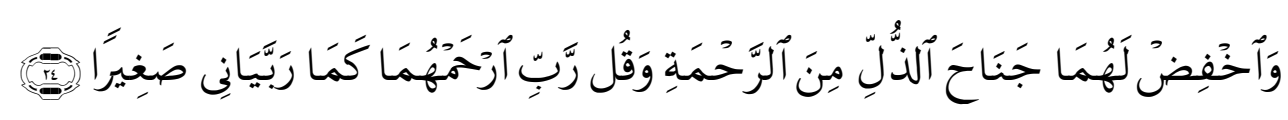

Artinya: "dan rendabkanlah dirimu terhadap mereka berdua dengan penuh kesayangan dan ucapkanlah: "Wahai Tubanku, kasibilah mereka keduanya, sebagaimana mereka berdua telah mendidik aku waktu kecil".22

Jadi lafadz "tarbiyah" dalam Alquran dimaksudkan sebagai proses pendidikan. Namun makna pendidikan (tarbiyah) dalam Alquran tidak terbatas pada aspek kognitif berupa pengetahuan untuk selalu berbuat baik kepada orang tua akan tetapi pendidikan juga meliputi aspek afektif yang direalisasikan sebagai apresiasi atau sikap respek terhadap keduanya dengan cara menghormati mereka. Lebih dari itu konsep tarbiyah bisa juga sebagai tindakan untuk berbakti bahkan sampai kepedulian untuk mendoakannya supaya mereka mendapatkan rahmat dari Allah yang maha kuasa. Pada ayat kedua dikatakan bahwa pendidikan itu ialah mengasuh. Selain mendidik, mengasuh juga hendak memberikan perlindungan dan rasa aman. Jadi term tarbiyah dalam Alquran tidak sekedar merupakan upaya pendidikan pada umumnya term itu menembus aspek etika religius.

2. Al-Ta'lim

Al-Ta'lim merupakan kata benda buatan (mashdar) yang berasal dari akar kata 'allama. Istilah tarbiyah diterjemahkan dengan pendidikan, sedangkan ta'lim diterjemahkan dengan pengajaran $^{23}$. Dalam Alquran dinyatakan, bahwa Allah mengajarkan manusia apa yang tidak diketahuinya. Sebagaimana firman Allah dalam beberapa ayat Alquran berikut:

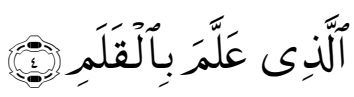

Artinya: "yang mengajar (manusia) dengan perantaran kalam". ${ }^{24}$

20 Jamali Sahrodi, Membedah Nalar Pendidikan Islam, Pengantar Ke Arab Ilmu Pendidikan Islam (Yogyakarta: Pustaka Rihlah Group, 2005), 42.

${ }^{21}$ Abdul Mujib dan Jusuf Mudzakkir, Ilmu Pendidikan Islam (Jakarta: Kencana, 2006), 13.

22 QS. Al-Isra', 17:24.

${ }^{23}$ Musthofa Rahman, Pendidikan Islam dalam Perspektif Alquran (Yogyakarta: Pustaka Pelajar, 2001), 60.

24 QS. Al-'Alaq, 96: 4.

8 | Tarbiyatuna: Jurnal Pendidikan Islam; Volume 13, Nomor 1, Februari 2020 p-ISSN: 2085-6539; e-ISSN: 2242-4579 


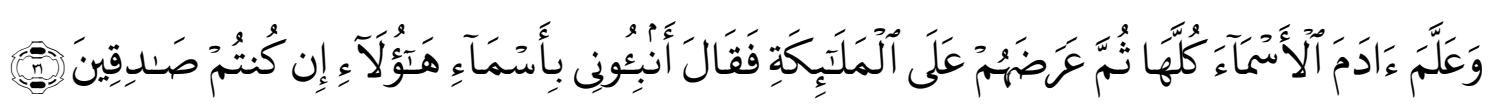

Artinya: "dan Dia mengajarkan kepada Adam Nama-nama (benda-benda) selurubnya, kemudian mengemukakannya kepada Para Malaikat lalu berfirman: "Sebutkanlah kepada-Ku nama benda-benda itu jika kamu mamang benar orang-orang yang benar!"125

Jadi, kata ta'lim atau 'allama dalam Alquran ditujukan sebagai proses pengajaran, pemberian informasi dan pengetahuan kepada peserta didik.

3. Al-Ta'dib

Istilah ta'dib berasal dari akar kata addaba, yuaddibu, ta'diiban yang mempunyai arti antara lain: membuatkan makanan, melatih akhlak yang baik, sopan santun, dan tata cara pelaksanaan sesuatu yang baik. Kata addaba yang merupakan asal kata dari ta'dib disebut juga muallim, yang merupakan sebutan orang yang mendidik dan mengajar anak yang sedang tumbuh dan berkembang. ${ }^{26}$ Ta'dib lazimnya diterjemahkan dengan pendidikan sopan santun. Ta'dib yang seakar dengan adab memiliki arti pendidikan, peradaban atau kebudayaan. Artinya orang yang berpendidikan adalah orang yang berperadaban, sebaliknya, peradaban yang berkualitas dapat diraih melalui pendidikan. ${ }^{27}$

Mengenai pengertian pendidikan Islam secara umum, para ahli pendidikan Islam memberikan batasan yang sangat bervariatif. Diantaranya adalah:

1. Muhammad Fadhil al-Jamaly: mendefinisikan pendidikan Islam sebagai upaya mengembangkan mendorong serta mengajak peserta didik hidup lebih dinamis dengan berdasarkan nilai-nilai yang tinggi dan kehidupan yang mulia. Dengan proses tersebut diharapkan akan terbentuk pribadi peserta didik yang sempurna, baik yang berkaitan dengan potensi akal, perasaan maupun perbuatannya. ${ }^{28}$

2. Ahmad D. Marimba: mengemukakan bahwa pendidikan Islam adalah bimbingan atau pemimpin secara sadar oleh pendidik terhadap perkembangan jasmani dan rohani peserta didik menuju terbentuknya kepribadian yang utama (insan kamil). ${ }^{29}$

3. Ahmad Tafsir: mendefinisikan pendidikan Islam sebagai bimbingan yang diberikan oleh seseorang agar ia berkembang secara maksimal sesuai dengan ajaran Islam. ${ }^{30}$

4. Hery Noer Aly: pengertian pendidikan Islam yaitu proses yang dilakukan untuk menciptakan manusia yang seutuhnya, beriman dan bertakwa kepada Tuhan serta mampu mewujudkan ekstensinya sebagai khalifah Allah dimuka bumi, yang berdasarkan

\footnotetext{
${ }^{25}$ QS. Al-Baqarah, 2: 31.

${ }^{26}$ Munardji, Ilmu Pendidikan Islam (Jakarta: PT Bina Ilmu, 2004), 4-5.

${ }^{27}$ Rahman, Pendidikan Islam dalam Perspektif Alquran, 17.

${ }_{28}$ Muhammad Fadhil Al-Jamaly, Nabwa Tarbiyat Mukminat (t.tt, 1977), 3.

${ }^{29}$ Ahmad D. Marimba, Pengantar Filsafat Pendidikan Islam (Bandung Al-Ma'arif 1989), 19.

30 Ahmad Tafsir, Ilmu Pendidikan dalam Perspektif Islam (Bandung: Remaja Rosdakarya, 1992), 32.
} 
ajaran Alquran dan sunnah, maka tujuan dalam konteks ini berarti terciptanya insaninsan kamil setelah proses pendidikan berakhir. ${ }^{31}$

Berdasarakan pendapat-pendapat ilmuan di atas dapat disimpulkan bahwa pendidikan Islam adalah suatu sistem yang memungkinkan seseorang (peserta didik) dapat mengarahkan kehidupannya sesuai dengan ideologi Islam dan pendidikan Islam itu lebih banyak ditujukan kepada perbaikan sikap mental yang akan terwujud dalam amal perbuatan, baik bagi keperluan diri sendiri maupun keperluan orang lain. ${ }^{32}$

\section{Pendekatan Pendidikan Islam}

Perwujudan strategi pendidikan Islam dapat dikonfigurasikan dalam bentuk metode pendidikan yang lebih luasnya mencakup pendekatan (approach)-nya. Untuk pendekatan pendidikan Islam, dapat berpijak pada firman Allah SWT, sebagai berikut:

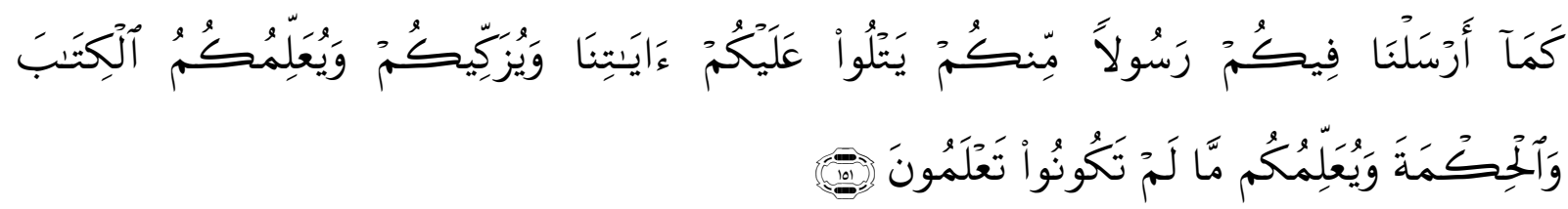

Artinya : "Sebagaimana (kami telah menyempurnakan nikmat Kami kepadamu) Kami telah mengutus kepadamu Rasul diantara kamu yang membacakan ayat-ayat Kami kepada kamu dan mensucikan kamu dan mengajarkan kepadamu Al kitab dan Al-Hikmah, serta mengajarkan kepada kamu apa yang belum kamu ketabui." (QS. Al-Baqarah: 151)

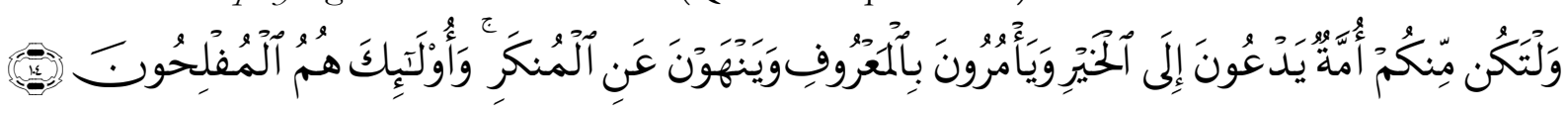

Artinya : "Dan hendaklah ada di antara kamu segolongan umat yang menyeru kepada kebajikan, menyuruh kepada yang ma'ruf dan mencegah dari yang munkar, merekalah orang-orang yang beruntung."'(QS. Ali Imran: 104).

Dari keduan firman Allah itu, menurut Jalaluddin Rahmat dan Zainal Abidin Ahmad yang dikutip oleh Abdul Mujib merumuskan pendekatan pendidikan Islam dalam enam kategori, yaitu:

1. Pendekatan Tilawah (Pengajaran)

Pendekatan tilawah ini meliputi membacakan ayat-ayat Allah yang bertujuan memandang fenomena alam sebagai ayat-Nya, mempunyai keyakinan bahwa semua ciptaan Allah memiliki keteraturan yang bersumberkan dari Rabb al-'alamin, serta memandang bahwa segala yang ada tidak diciptakan-Nya secara sia-sia belaka. Bentuk tilawah mempunyai indikasi tafakkur (berpikir dan tadzakur (berzikir).

2. Pendekatan Tazkiyah (Penyucian)

Pendekatan ini meliputi penyucian diri dengan upaya amar ma;ruf dan nabi mungkar (tindakan proaktif dan tindakan reaktif). Pendekatan ini bertujuan untuk memelihara

\footnotetext{
${ }^{31}$ Hery Noer Aly, Ilmu Pendidikan Islam (Jakarta: Logos Wacana Ilmu, 1999), 5.

${ }^{32}$ Djumransyah, Filsafat Pendidikan Islam (Malang: Bayumedia, 2006), 117.

10 | Tarbiyatuna: Jurnal Pendidikan Islam; Volume 13, Nomor 1, Februari 2020 p-ISSN: 2085-6539; e-ISSN: 2242-4579
} 
kebersihan diri dari lingkungannya, memelihara dan mengembangkan akhlak yang baik, menolak dan menjauhi akhlak tercela, berperan serta dalam memlihara kesucian lingkungannya. Indikator pendekatan ini adalah fisik, psikis, dan sosial.

3. Pendekatan Ta'lim Al-Kitab

Mengajarkan Al-Kitab (Al-Qur'an) dengan menjelaskan hukum halal dan haram. Pendekatan ini bertujuan untuk membaca, memahami, dan merenungkan Al-Qur'an dan AsSunnah sebagai keterangannya. Pendekatan ini bukan hanya memahami fakta, tetapi juga makna dibalik fakta, sehingga dapat menafsirkan informasi secara kreatif dan produktif.

4. Pendekatan Ta'lim Al-Hikmah

Pendekatan ini hampir sama dengan pendekatan Ta'lim Al-Kitab, hanya saja bobot dan proporsinya serta frekuensinya diperluas dan diperbesar. Indicator utama dari pendekatan ini adalah mengadakan perenungan (reflective thingking), renovasi, dan interpretasi terhadap pendekatan Ta'lim Al-Kitab.

\section{Yuallim-kum ma lam takunu ta'lamun}

Suatu pendekatan yang mengajarkan suatu hal yang memang benar-benar asing dan belum diketahui, sehingga pendekatan ini membawa peserta didik pada suatu alam pemikiran yang benar-benar luar biasa. Pendekatan ini mungkin hanya dinikmati oleh nabi dan rasul saja, seperti adanya mu’jizat, sedangkan manusia biasa hanya menikmati sebagian kecil saja.

6. Pendekatan Ishlah (Perbaikan)

Pelepasan beban dan belenggu-belenggu yang bertujuan memiliki kepekaan terhadap penderitaan orang lain, sanggup menganalisis kepincangan-kepincangan yang lemah, memiliki komitmen memihak bagi kaum yang tertindas, dan berupaya menjembatani perbedaan paham. $^{33}$

\section{Lokasi Riset}

Lokasi riset ini dilakukan di desa Meninjo Kecamatan Ranuyoso Kabupaten Lumajang. Secara sosiologis, masyarakat desa Meninjo Kecamatan Ranuyoso Kabupaten Lumajang merupakan salah satu desa yang penduduknya agamis, namun kalangan anak-anak muda lebih memilih untuk bekerja atau menikah di usia dini dari pada melanjutkan pendidikannya. Keadaan ini membuat masyarakat desa Meninjo memandang petuah-petuah Kiai Langgar adalah suatu hal yang wajib untuk dilakukan. Karena pendidikan Islam masyarakat Meninjo berada di pundak Kiai Langgar yang memiliki peranan yang sangat penting dalam menjaga stabilitas pendidikan Islam.

33 Abdul Mujib, Imu Pendidikan Islam (Jakarta: Kencana Putra Grafika, 2006), 176-179 
Tidak hanya itu, Kiai langgar dinilai mampu menjadi pemimpin dalam urusan penyebaran dan penjagaan nilai pendidikan Islam.

\section{Sejarah Berdirinya Desa Meninjo Ranuyoso Kabupaten Lumajang}

Desa Meninjo berdiri pada tahun 1893-an, dulunya desa Meninjo sebenarnya adalah hutan rimba. Namun karena pertumbuhan penduduk di wilayah sekitar hutan, akhirnya sedikit demi sedikit penduduk membabati hutan tersebut maka terjadilah wilayah-wilayah kecil kemudian banyak penduduk yang melakukan hal yang sama. Karena semakin banyak wilayah dan penduduk akhirnya mereka sepakat untuk mendirikan sebuah desa yang dinamakan Desa Meninjo. Konon desa ini dijuluki desa perempuan oleh warga desa lain, karena desa ini merupakan desa yang damai, tentram dan tidak pernah terjadi perselisihan anatar warganya. Sehingga banyak desa lain yang meninjau kebiasaan desa tersebut, maka dinamakanlah desa tersebut desa Meninjo yang berasal dari kata tinjau (meninjau). ${ }^{34}$

Letak Geografis desa Meninjo sebelah utara berbatasan dengan Desa Wonoayu, sebelah timur berbatasan dengan Desa Tegal Bangsri, sebelah selatan berbatasan dengan Desa Tegal Ciut dan Sebelah barat berbatasan dengan Desa Jenggrong. Desa Meninjo berada di ketinggian 179 M dari permukaan laut dan termasuk topografi dataran rendah. Banyaknya curah hujan 4-8 MM perhari membuat suhu rata-rata di desa Meninjo $\pm 24^{\circ} \mathrm{C}-30^{\circ} \mathrm{C} .{ }^{35}$

\section{Kegiatan Keagamaan di Desa Meninjo}

Di Meninjo terdapat berbagai kegiatan yang rutin dilaksanakan oleh masyarakat. baik itu kegiatan yang bersifat keagamaan maupun kegiatan sosial. Kegiatan keagamaan yang dilaksanakan di Meninjo ini dipimpin oleh kiai langgar yang ada. Berbagai kegiatan tersebut yaitu : ${ }^{36}$

1. Taman Pendidikan Al-qur'an

TPA merupakan kepanjangan dari Taman Pendidikan al-Qur'an. Kegiatan ini diikuti oleh anak-anak bahkan sampai umur dewasa. Didalam kegiatan TPA ini diajarkan berbagai ilmu agama mulai dari belajar Shalat, menulis dan membaca ayat al-Qur'an, tajwid dan belajar kitab- kitab lain. Kegiatan TPA ini dilaksanakan di rumah-rumah kiai langgar yang juga diasuh oleh kiai langgar tersebut.

Nama Langgar dan Masjid beserta Imamnya

\begin{tabular}{|c|l|l|c|}
\hline No & \multicolumn{1}{|c|}{ Nama } & \multicolumn{1}{|c|}{ Imam } & Lokasi \\
\hline 1 & Nurul Huda (Masjid) & Muhammad Sudi & RT 03 \\
\hline 2 & An-Nur (Masjid) & Mukhlis & RT 01 \\
\hline
\end{tabular}

\footnotetext{
${ }^{34}$ Data dokumentasi arsip Desa Meninjo: Kecamatan Ranuyoso dalam Angka 2017, 10

${ }^{35}$ Data, $10-11$

36 Observasi di Desa Meninjo, 10 Mei 2019

12 | Tarbiyatuna: Jurnal Pendidikan Islam; Volume 13, Nomor 1, Februari 2020 p-ISSN: 2085-6539; e-ISSN: 2242-4579
} 


\begin{tabular}{|c|l|l|c|}
3 & Riadhul Jannah (Masjid) & Ahmad Suharyanto & RT 06 \\
\hline 4 & Raudhotul Muta'allimin (Masjid) & Mahrus & RT 08 \\
\hline 5 & Jami' Al Falah (Masjid) & Fathur Rozi & RT 16 \\
\hline 6 & Al-Ihsan (Langgar) & Muhtar & RT 16 \\
\hline 7 & Miftahul Ulum (Langgar) & Fathur & RT 16 \\
\hline 8 & Unwanul Falah (Langgar) & Muhammad Al-Haddad & RT 16 \\
\hline 9 & Baitul Amin (Langgar) & Muklas & RT 05 \\
\hline 10 & Ainul Yaqin (Langgar) & Atmari & RT 02 \\
\hline
\end{tabular}

Delapan masjid atau Mushalla yang ada di Meninjo tersebut dapat membantu menciptakan masyarakat yang agamis di desa Meninjo. Di setiap waktu shalat berkumandang suara adzan dari kedelapan masjid atau Mushalla tersebut. Selain untuk Shalat berjama'ah, masjid dan langgar juga digunakan untuk tempat pengajian seperti pengajian selapanan dan lain-lain. Sedangkan beberapa nama TPQ atau TPA yang ada di Meninjo adalah sebagai berikut:

Nama TPA beserta pengasuh dan jumlah santri

\begin{tabular}{|c|l|l|c|c|}
\hline No & \multicolumn{1}{|c|}{ Nama } & \multicolumn{1}{|c|}{ Pengasuh } & Jumlah Santri & Lokasi \\
\hline 1 & Al-Ihsan & Muhtar & 20 & RT 16 \\
\hline 2 & Miftahul Ulum & Fathur & 55 & RT 16 \\
\hline 3 & Unwanul Falah & Muhammad Al-Haddad & 74 & RT 16 \\
\hline 4 & Baitul Amin & Muklas & 17 & RT 05 \\
\hline 6 & Nurul Yaqin & Mukhlis & 37 & RT 01 \\
\hline 7 & TPA & Eko Suharyanto & 23 & RT 02 \\
\hline
\end{tabular}

Dari 7 Kiai Langgar yang ada sangat berperan bagi kehidupan masyarakat Meninjo terutama dalam bidang keagamaan. Kiai Langgar yang ada hidup bersama berbaur dengan masyarakat tanpa ada jarak apapun sehingga masyarakat merasa dekat dan bebas menanyakan apapun kepada Kiai Langgar. Kiai Langgar selalu menjadi pemimpin dalam kegiatan apapun khususnya kegiatan keagamaan.

2. Khataman Al-qur'an

Acara ini merupakan acara khataman yang dilaksanakan oleh tiap-tiap TPA setiap satu bulan sekali. Kegiatan ini dilaksanakan juga untuk meningkatkan semangat para santri agar rajin dalam mengaji.

3. Pengajian Mingguan

Pengajian mingguan yang ada di Meninjo adalah pengajian yang dilaksankan setiap satu minggu sekali, yaitu setiap hari jum'at sore sekitar jam 4 atau ba'da ashar, di rumah kiai langgar yang bernama Kiai Muhtar dilaksanakan pengajian yang didikuti oleh bapak-bapak dan ibu-ibu di desa Meninjo. Sehingga dengan pengajian ini dapat menambah penggetahuan agama masyarakat Meninjo. 
4. Perayaan Hari-hari Besar di Desa Meninjo

Perayaan hari besar ini dilaksanakan di saat hari hari besar Islam seperti:

a) Hari Raya Idul Adha dan Hari Raya Idul Fitri

Di dua hari raya ini diadakan shalat Ied bersama-sama. Pada hari raya Idul Adha dilkasanakan acara qurban dan pada hari raya Idul Fitri masyarakat berkunjung kerumah tetangga-tetangga untuk bersalam-salaman meminta maaf.

b) Maulid Nabi Muhammad SAW

Acara yang dilaksanakan disetiap RT pada tanggal 12 Rabiul Awal untuk memperingati kelahiran nabi Muhammad (Maulud Nabi) dengan membaca shalawat di Mushollah yang ada di setiap RT

c) Isra' Mi'raj Nabi Muhammad SAW

Acara yang dilaksanakan sebelum memasuki bulan puasa Ramadhan, masyarakat desa Meninjo biasa menyebutnya dengan Rejeban.

\section{Kiai Langgar dan Pendidikan Islam di Desa Meninjo Kecamatan Ranuyoso Lumajang}

Sebagaimana telah disebutkan sebelumnya, Kiai Langgar adalah kiai yang hidup di pedesaan, ataupun orang yang menjadi guru agama yang biasa disebut dengan guru ngaji. Kiai Langgar merupakan kiai yang hidup di tengah masyarakat dan menyatu dengan masyarakat tanpa ada jarak apapun. Kedekatan Kiai Langgar dengan masyarakat terlihat ketika kiai selalu mengikuti kegiatan yang dilaksanakan oleh masyarakat dan juga akan mengetahui dan berhadapan secara langsung dengan permasalahan masyarakat.

Peran Kiai Langgar dalam meningkatkan pendidikan Islam pada masyarakat di desa Meninjo sangatlah baik. Ada beberapa peningkatan pendidikan Islam terhadap masyarakat baik anak-anak maupun orang dewasa, yaitu dalam bentuk pembiasaan yang menjadi pembiasaan yang sangat baik, seperti yang diungkapkan oleh bapak Sholihin salah satu masyarakat di desa Meninjo. Beliau menuturkan :

"Kiai sangat berperan bagi masyarakat di Desa Meninjo, terutama bagi saya sendiri, karena masyarakat sangat antusias dengan ajakan kiai untuk mengadakan kegiatan-kegiatan yang berhubungan dengan hal keagamaan, seperti sholawatan ataupun yasinan yang dilaksanakan setiap satu minggu sekali. ${ }^{37}$

Informan lain juga mengatakan :

"Masyarakat di Desa Meninjo selalu melibatkan kiai dalam kegiatan keagamaan seperti Yasinan, karena kiai yang dijadikan imam dalam kegiatan tersebut" ${ }^{\prime 3}$

\footnotetext{
${ }^{37}$ Sholihin, Wawancara, 25 April 2019

38 Atmari, Wawancara, 25 April 2019

14 | Tarbiyatuna: Jurnal Pendidikan Islam; Volume 13, Nomor 1, Februari 2020 p-ISSN: 2085-6539; e-ISSN: 2242-4579
} 
Adapun hubungan Kiai Langgar dalam manifestasi pendidikan Islam pada masyarakat di desa Meninjo memiliki peran sebagai berikut:

1. Kesadaran Masyarakat

Kiai Langgar berperan sebagai guru ngaji atau yang mengajarkan ilmu agama Islam kepada anak-anak sampai remaja bahkan kepada orang dewasa. Perkembangan pendidikan Islam pada masyarakat di desa Meninjo sangatlah baik, ada beberapa kegiatan keagamaan yang dilaksanakan oleh kiai sehingga membentuk kebiasaan yang terhadap masyarakat. Dalam hal ini salah seorang Kiai langgar yang bernama Kiai Mukhtar mengatakan :

“ Perkembangan pendidikan Islam pada masyarakat di Desa Meninjo dari tahun ke tahun semakin meningkat, hal itu dilihat dari bertambahnya jamaah yang ikut dalam acara pengajian yang saya adakan setiap satu minggu sekali di mushollah saya sendiri, kegiatan tersebut saya awali dengan membaca surat yasin bersema, kemudian tahlil baru setelah itu mauidhah hasanah dan yang terakhir adalah Do'a" ${ }^{39}$

Selain acara pengajian yang diadakan setiap minggu untuk mengembangkan kesadaran pendidikan Islam pada masyarakat, kiai beserta ibu nyai juga mengajarkan kepada santri tentang ilmu kegamaan. Ibu nyai menjelaskan bagaimana perkembangan pengetahuan tentang agama Islam santri-santrinya. Beliau menuturkan :

"Selain menjadi guru ngaji, kami juga mengajarkan bagaimana menjadi manusia yang barakhlaq mulia. Contohnya, kami mengajarkan bagaimana cara menghormati orang yang lebih tua, menjelaskan hal-hal yang halal dan haram dilakukan, menjelaskan dampak-dampak jika melakukan sesuatu yang buruk sehingga kami bisa membentuk kepribadian yang baik bagi santri kami’".

Ustadz Eko selaku Kiai langgar juga mengatakan :

"Perkembangan pendidikan Islam masyarakat jika dibandingkan zaman dulu dan sekarang sangat jauh berbeda, dulu orang dewasa berfikir sudah tidak pantas lagi untuk mengaji di langgar-langgar, berbeda dengan sekarang, selain saya memiliki santri anak-anak dan remaja, justru sekarang santri saya juga banyak dari kalangan orang dewasa. Mereka sangat antusias sekali untuk menambah pengetahuan tentang agama Islam",41

Salah seorang masyarakat sekaligus santri dari ustadz Eko juga mengatakan:

"Dulu sebelum saya belajar bersama ustadz Eko, saya tidak bisa membaca Alqur'an, karena waktu masih kecil memang tidak pernah mengaji. Alhamdulillah setelah saya belajar bersama beliau sekarang sudah mulai bisa membaca Al-Qur'an. Selain belajar membaca Al-qur'an, Ustadz Eko juga mengajarakan kitab kuning. Sehingga saya sudah mulai paham dengan ilmu-ilmu tentang agama Islam". ${ }^{42}$

${ }^{39}$ Kiai Muhtar, Wawancara, 14 Mei 2019

40 Ibu Nyai Mukhtar, Wawancara, 14 Mei 2019

${ }^{41}$ Ustadz Eko, Wawancara, 15 Mei 2019

42 Sanan, Wawancara, 15 Mei 2019 
2. Membentuk Manusia yang Beriman

Keimanan merupakan salah satu faktor terpenting, karena keimanan dan ketaqwaan merupakan dasar akidah yang diperkuat. Menurut ustadz Eko selaku salah satu Kiai langgar Menuturkan:

"keimanan merupakan landasan pokok bagi kehidupan manusia sesuai dengan fitrahnya, karena manusia mempunyai kecenderungan untuk mengalami dan mempercayai adanya Tuhan, untuk itu penanaman keimanan tidak boleh dilupakan dan disepelekan"

Ahmad Taufik selaku salah satu santri dari Ustadz Eko, menjelaskan:

"Saya merasa senang saat ustadz menerangkan tentang keimanan, karena dengan kegiatan ini setidaknya setiap hari saya mendapatkan siraman rohani dan mendapatkan ilmu. Melalui kegiatan ini saya lebih bisa meningkatkan keimanan dari pada sebelumnya." 44

Ustadz eko juga menyampaikan bagaimana cara meningkatkan keimanan para santrinya. Beliau berkata :

"Saya mengajarkan kepada santri tentang perbuatan-perbuatan yang baik, mengajarkan kalimat syahadat atau kalimat tauhid. Apabila santri ternyata melakukan perbuatan yang tidak baik, ya saya mengatakan bahwa itu perbuatan yang tidak baik dan mengatakan bahwa jika seseorang melakukan perbuatanperbuatan yang tidak baik itu tandanya orang-orang yang tidak beriman,\$45

Selanjutnya beliau juga menuturkan bagaimana cara meningkatkan kesadaran pendidikan Islam masyarakat.

"Untuk menyadarkan masyarakat bahwa pendidikan Islam sangat penting pertama saya memberikan nasehat-nasehat, memberikan dorongan-dorongan dan pembelajaran melalui mauidzah-mauidzah, kedua malakukan pendekatan dan ketiga meberikan contoh"46

Berdasarakan hasil wawancara di atas disimpulkan bahwa peran Kiai langgar dalam meningkatkan pendidikan Islam Masyarakat terutama dalam hal keimanan melalu tiga cara yaitu: 1) Dengan cara memberikan mauidzah hasanah tentang keagamaan terutama masalah yang terjadi dalam kehidupan masyarakat, 2) Melakukan pendekatan terhadap masyarakat dengan mengikuti arus seperti apa kegiatan-kegiatan masyarakat tersebut dalam sehari-hari. 3) memberikan contoh, jadi tidak hanya berkata dan berkata kiai juga menjadi pedoman bagi masayarakat.

43 Ustad Eko, Wawancara, 15 Mei 2019

44 Ahamad Taufik, Wawancara, 15 Mei 2019

45 Ustad Eko, Wawancara, 15 Mei 2019

46 Ustad Eko, Wawancara, 15 Mei 2019

16 | Tarbiyatuna: Jurnal Pendidikan Islam; Volume 13, Nomor 1, Februari 2020 p-ISSN: 2085-6539; e-ISSN: 2242-4579 
3. Membentuk Manusia yang Berakhlaq

Kata akhlak berasal dari bahasa arab, yaitu bentuk jamak dari kata khulq, yang berarti tingkah laku, perangai, atau tabiat. Sedangkan menurut istilah, akhlak adalah daya kekuatan jiwa yang mendorong perbuatan dengan mudah dan spontan tanpa dipikir dan direnungkan lagi.

Seabagaimana yang dipaparkan oleh kiai Mukhtar selaku Kiai langgar di TPA Miftahul Ihsan :

"Kalau masalah akhlak atau etika sudah saya terapkan sebagaimana njenengan tadi liat bahwa antara santri dengan santri harus ada batasnya, karena di sini pedesaan jadi saya harus berusaha merubah akhlak mereka dengan cara menerangkan kitab sullam safina yang membahas tentang akhlak". ${ }^{47}$

Salah satu masyarakat yang bertetangga dengan TPA tersebut juga menuturkan :

"Alhamdulillah untuk Akhlak di TPA ini sudah baik, karena kiai mereka sudah menerangkan tentang berakhlaqul karimah. Jadi santri sudah bisa menjaga akhlaknya terhadap sesama apalagi terhadap orang yang lebih tua". ${ }^{48}$

Dari hasil wawancara di atas dapat disimpulkan bahwa akhlak atau etika diterapkan dari kitab sullam safina agar santri bisa berakhlak terpuji terhadap siapapun dan menghormati sesama makhluk ciptaan Allah SWT.

Berdasarkan observasi yang dilakukan oleh peneliti, menerangkan bahwa dengan diadakannya pengajian kitab sullam safinah tersebut, peneliti melihat para santri berperilaku sopan terhadap orang yang lebih tua.

4. Manusia yang berilmu

Ilmu juga marupakan hal yang sangat penting dalam kehidupan manusia, karena dengan ilmu manusia bisa membedakan mana yang baik dan mana yang buruk. Berikut penuturan Ustadz Eko selaku salah satu Kiai langgar di desa Meninjo :

"saya mengajarkan masayarakat terutama para santri supaya menjadi orang yang berilmu, karena dengan ilmu seseorang bisa membedakan mana pebuatan yang baik dan mana perbuatan yang buruk. Begitu juga bagi santri yang kelak akan akan melanjutkan pendidikan selanjutnya atau melanjutkan ke pesantren, mereka sudah sedikit banyak paham dengan ilmu agama"49

Jadi, para kiai langgar mengajarkan bagaimana cara membaca Al-Qur'an yang benar, dengan mengajarkan ilmu tajwid, Makhroj yang tepat dan mengajarkan cara memebaca AlQur'an dengan tartil. Dengan hal tersebut kiai langgar mengharapkan supaya para santri tidak kesulitan ketika melanjutkan di Pondok Pesesantren ataupun ke pendidikan yang lebih tinggi.

\footnotetext{
${ }^{47}$ Kiai Muhtar, Wawancara, 17 Mei 2019

${ }^{48}$ Qomaruddin, Wawancara, 17 Mei 2019

${ }^{49}$ Ustad Eko, Wawancara, 15 Mei 2019
} 


\section{Kiai langgar dalam Pandangan Masyarakat}

Masyarakat desa Meninjo merupakan masyarakat yang terlihat sangat agamis. Di sana terdapat 7 Kiai langgar yang dapat mewarnai keseharian masyarakat. Kiai langgar memang sangat berperan dalam berbagai kegiatan yang dilaksanakan oleh masyarakat Meninjo.

Dari hasil wawancara yang peneliti lakukan telah membuktikan bahwa masyarakat desa Meninjo merasa bahwa Kiai langgar yang ada sangat diperlukan keberadaannya karena dapat membantu dan mendukung segala kegiatan yang ada terutama kegiatan spiritual keagamaan. Dan Kiai langgar lah yang perperan memberikan modal dasar dalam pendidikan agama islam kepada anak-anak dan juga berusaha meningkatkan pengetahuan agama kepada masyarakat luas dengan cara mengisi ceramah atau pengajian.

Peneliti juga mengadakan wawancara dengan bapak Muhammad Bedrus selaku perangkat desa, beliau mengatakan:

"Kiai sangat membantu kegiatan di desa terutama di bidang spiritual keagamaan dan keberadaannnya sangat diperlukan masyarakat karena dapat dijadikan sebagai pedoman hidup dalam bertindak sesuai dengan hukum agama". ${ }^{0}$

Mengenai hal yang sama Bapak Hosirin selaku ketua RW juga menuturkan :

"Kiai Langgar sangat bermanfaat bagi masyarakat karena kiai dapat menuntun dan mengajak masyarakat menuju jalan yang benar dan dapat meluruskan dari sesuatu yang buruk". 51

Dari beberapa penuturan masyarakat Meninjo di atas terlihat bahwa masyarakat sangat memerlukan keberadaan Kiai langgar karena dapat dijadikan sebagai pembimbing dan dapat berperan sebagai pendidik masyarakat dalam belajar ilmu agama dan dapat dijadikan sebagai panutan hidup.

Menurut masyarakat Kiai langgar juga berperan ketika ada warga yang meninggal dunia. Dalam pengurusan jenazah ini kiai kampung berperan sebagai pemimpin mulai dari memandikan, mengkafani, menshalatkan, mengiringi jenazah sampai dengan pemakaman. Disamping itu kiai juga mengajarkan kepada masyarakat bagaimana tata cara merawat jenazah :

"Kiai kampung dibutuhkan ketika ada orang yang meniggal dunia, karena kiai kampung lebih paham dalam hal pengurusan jenazah, seperti memandikan, mengkafani, menshalatkan dan sampai penguburan" ${ }^{2}$

Dari sini terlihat bahwa memang keberadaan Kiai langgar sangat berperan dalam kehidupan masyarakat. dan ini bisa dikatakan sejak lahir sampai meninggal. Karena kiai selalu dijadikan pemimpin dalam acara yang dilaksanakan oleh masyarakat.

\footnotetext{
${ }^{50}$ Muhammad Badrus, Wawancara, 20 Juni 2019

${ }^{51}$ Hosirin, Wawancara, 20 Juni 2019

${ }^{52}$ Yusuf, Wawancara, 20 Juni 2019

18 | Tarbiyatuna: Jurnal Pendidikan Islam; Volume 13, Nomor 1, Februari 2020 p-ISSN: 2085-6539; e-ISSN: 2242-4579
} 
Selain itu, dengan adanya Kiai langgar masyarakat merasakan ketentraman dalam hidup karena Kiai langgar dapat mengarahkan masyarakat dalam bertindak dan mengajarkan kepada masyarakat untuk berbuat kebaikan. Berikut penuturan dari Muhammad salah satu masyarakat desa Meninjo :

"Dengan adanya kiai, keadaan masyarakat menjadi tentram karena kiai dapat menjadi penengah jika ada konflik dalam masyarakat, apalagi seperti saat ini yang lagi panas-panasnya dengan masalah politik" 53

Bapak Mahfud juga mengatakan :

"Saya bersyukur karena dengan adanya kiai, dapat membantu persoalan-persoalan yang terjadi di tengah-tengah masayarakat khususnya di desa Meninjo. Sepeti yang saya lihat saat ini dari sekian banayak perbedaan dan konflik yang terjadi pada masyarakat, kiai lah yang menjadi penengah supaya tidak terjadi pertengkaran" ${ }^{54}$

Masyarakat merupakan kumpulan orang banyak yang antara satu dengan yang lain saling memilki perbedaan. Memang dari hasil wawancara yang telah peneliti laksanakan terlihat bahwa anggapan masyarakat desa Meninjo mengatakan bahwa keberadaan Kiai langgar sangatlah dibutuhkan oleh masyarkat.

Selain tanggapan masyarakat di atas, menurut pengamatan penulis ternyata masyarakat desa Meninjo juga menganggap bahwa kiai adalah orang yang memiliki barokah. Masyarakat sering mengharapkan barokah dari kiai. Meskipun konsep barokah yang ada tidak se-ekstrim konsep barokah yang dilakukan kepada para kiai-kiai besar, seperti halnya mengambil sisa makanan kiai, bekas air wudlu kiai, sandal sang guru dan ketundukan yang sangat berlebihan. Sebagian masyarakat berpendapat bahwa semua itu merupakan jalan atau wasilah untuk mendapatkan barokah dari Allah SWT melalui seorang kiai, karena beliau adalah orang yang dekat dengan Allah SWT.

Barokah juga ditemukan ketika ada acara pengajian atau sejenisnya. Di sini peneliti melihat bahwa ketika masyarakat bersalaman dengan kiai tidak seperti bersalaman dengan masyarakat pada umumnya. Masyarakat bersalaman dengan kiai tersebut dengan menundukkan badan dan mencium tangan kiai tersebut.

\section{Kesimpulan}

Peran Kiai langgar dalam meningkatkan Pendidikan Islam pada masyarakat di desa Meninjo kecamatan Ranuyoso kabupaten Lumajang setidaknya dapat disimpulkan sebagai berikut:

\footnotetext{
${ }^{53}$ Muhammad, Wawancara, 20 Juni 2019

54 Mahfud, Wawancara, 20 Juni 2019
} 
1. Meningkatkan keimanan masyarakat, yaitu yang berkaitan dengan pendidikan keimanan, seperti percaya kepada Allah, malaikat, rasul, kitab, hari akhir, dan takdir yang bertujuan untuk menata kepercayaan individu.

2. Meningkatkan akhlaq masyarakat, yang berkaitan dengan pendidikan etika, yang bertujuan membersihkan diri dari perilaku rendah dan menghiasi diri dari perilaku terpuji.

3. Meningkatkan masyarakat sebagai manusia yang berilmu, yang berkaitan dengan pengetahuan masyarakat terhadap perbuatan-perbuatan yang baik dan buruk, perbuatan yang benar dan salah serta menyadarkan masyarakat bahwa pendidikan Islam itu sangat penting baik dikehidupan dunia dan akhirat.

Adapun tanggapan masayarakat terhadap upaya Kiai langgar dalam meningkatkan pendidikan Islam di desa Meninjo kecamatan Ranuyoso kabupaten Lumajang beragam, tetapi secara keseluruhan menunjukkan respon positif. Keberadaan Kiai langgar yang ada di desa Meninjo sangat baik dan didukung masyarakat. Masyarakat beranggapan Kiai Langgar selain sebagai pendidik agama Islam, Kiai langgar juga merupakan penjaga moral masyarakat dan tempat masyarakat meminta bantuan tentang berbagai persoalan kehidupannya, Kiai Langgar menjadi semacam rujukan bagi masyarakat dalam berbagai kehidupan.

\section{Referensi}

Achidsti, Sayfa Auliya. “Esistensi Kiai Dalam Masyartakat” Jurnal Kebudayaan Islam (2014): 149.

Aly, Hery Noer. 1999. Ilmu Pendidikan Islam. Jakarta: Logos Wacana Ilmu.

Basrowi \& Suwandi. 2008. Memahami Penelitian Kualitatif. Jakarta: Rineka Cipta.

Dhakri, M. Hanif. 2007. Kiai Kampung dan Demokrasi Lokal. Yogyakarta:KLIK.

Djumransyah. 2006. Filsafat Pendidikan Islam. Malang: Bayumedia.

Eko. Wawancara. Meninjo, 10 Maret 2019. "Salah seorang yang berperan sebagai Kiai Langgar di Desa Meninjo"

Halim, Abdul. 2002. Filsafat Pendidikan Islam: Pendekatan Historis, Teoris dan Praktis. Jakarta: Ciputat Pers.

Hasan, Iqbal. 2002. Pokok-Pokok Materi Metodologi Penelitian dan Aplikasinya. Jakarta: Ghalia Indonesia.

Kosim, Mohammad. "Langgar Sebagai Institusi Pendidikan Keagamaan Islam”. Jurnal Tadrîs, (2009): 237.

Marzuqoh, Nuhaya Alina, "Peran Sosial Kiai Kampung di Desa Salamrejo Kecamatan Selopampang Kabupaten Temanggung ", Skripsi, Universitas Negeri Sunan Kalijogo, Yogyakarta, 2008.

Marimba, Ahmad D. 1998. Pengantar Filsafat Pendidikan Islam. Bandung Al-Ma'arif.

Mujib, Abdul dan Jusuf Mudzakkir. 2006. Ilmu Pendidikan Islam. Jakarta: Kencana. 
Muhammad Aufal Minan, "Peran Kyai Dalam Pendidikan Moral Masyrakat Nelayan di Desa Karangaji Kecamatan Kedung Kabupaten Jepara ”, Skripsi, Universitas Negeri Sunan Kalijogo, Yogyakarta, 2005, 6

Munardji, 2005. Ilmu Pendidikan Islam. Jakarta: PT Bina Ilmu.

Rahman, Musthofa. 2001. Pendidikan Islam dalam Perspektif Alquran. Yogyakarta: Pustaka Pelajar.

Ramayulis., 2002. Ilmu Pndidikan Islam. Jakarta : Kalam Mulia. 1.

Sahrodi,Jamali. 2005. Membedah Nalar Pendidikan Islam, Pengantar Ke Arah Ilmu Pendidikan Islam. Yogyakarta: Pustaka Rihlah Group.

Sholichin, M. Muhlis "Tipologi Kiai Madura (Telaah Terhadap Silsilah Dan Keberagamaan Prilaku Kiai-Kiai Di Pamekasan)”. (2007): 44.

Syamsudini "Daya Tahan Penddikan Langgar Di Tengah Arus Modernisasi Pendidikan Islam", Jurnal al-'Adâlah. (2016): 19.

Tafsir, Ahmad. 1992. Ilmu Pendidikan dalam Perspektif Islam. Bandung: Ramaja Rosdakarya.

Untung, Moh. Slamet. "Telaah Historis Pertumbuhan Pusat Pendidikan Islam Di Jawa Sampai Periode Perang Jawa" Jurnal Forum Tarbiyah. 215-216.

Wardi, Moh. "Pilihan Belajar Al-Qur'an di Madura; Konversi Dari Langgar Ke Taman Pendidikan Al-Qur'an", Jurnal Kabilah. (2019): 93.

Wawardi, Mawarti. "Persepsi Masyarakat Terhadap Peran Kiai di Daerah Istimewa Yogyakarta”. Jurnal Medan Agama. (2014): 134. 